\title{
Technical Studies on Development of the Dobele Underground Natural Gas Storage Facility
}

\author{
Leo Jansons ${ }^{1}$, Namejs Zeltins ${ }^{2}$, \\ ${ }^{1,2}$ The Latvian Member Committee, World Energy Council
}

\begin{abstract}
Dobele structure is the only large scale underground water horizon structure in Latvia, except the existing Inčukalns UGS facility, suitable for creation of UGS, where the geological surveys have ever been carried out. Since 1970s 23 wells were drilled there, the exploratory activities of different scale continued in 1990 s and $2008-2010$. The results of the geological and well condition assessment done between 2008 - 2010 within the scope of the project "Geological and Economic Research of Possible Establishment of Natural Gas Storage Reservoirs in Latvia, Dobele District” 2006-G 130/06-TREN/06/TEN-E-S07.68968 confirmed that the technical condition of a few existing ground infrastructure elements (wells) in Dobele is satisfactory, but other elements, however, can no longer be used for operational or monitoring purposes.
\end{abstract}

Keywords - Natural gas, underground gas storages, Dobele, wells, environmental protection

\section{INTRODUCTION}

Underground gas storages (hereafter - UGS) are one of the core elements of gas supply system ensuring about $25 \%$ of the total gas consumption in winter season both in the European Union (hereafter - EU) and in the Russian Federation, which is one of the largest natural gas suppliers to the Europe. UGSs currently perform several important functions for stable and secure gas supply to the consumers, namely: levelling seasonal irregularity of the natural gas consumption; providing extra natural gas supply to the consumers in case of anomalously cold winter; ensuring export natural gas flows (Russia - the EU; for example gas supply to Latvia is ensured by means of Incukalns UGS); guaranteeing natural gas supply to the transmission pipelines in emergency situations. [1]

In the Baltic region (Lithuania, Latvia and Estonia) stability and security of the natural gas supply since late 1960s and early 1970s is guaranteed by the third largest aquifer underground gas storage in Europe - Incukalns UGS, with the total volume of 4.47 billion cubic meters (BCM), the active volume 2.32 BCM, and the planned increase of active gas volume up to $2.8 \mathrm{BCM}$ in the period of till 2025 .

Thereby, the amount of daily withdrawal of the natural gas from the storage would increase from 28-30 million cubic meters (MCM) till 34-35 MCM. [2]

Incukalns UGS is used seasonally, as the natural gas consumption in the Baltic region varies greatly in summer and winter periods due to the necessity to produce heating energy for both district and local heating systems mostly running on natural gas. The share of heat energy base load generation from the natural gas is bigger in Latvia and Lithuania than in
Estonia. The natural gas is injected into Incukalns UGS during April - October, when the natural gas demand in the region reaches the lowest point and makes about one quarter in comparison to winter demand, and withdrawn during the rest of the year. During that time, all the natural gas consumed in Latvia and Estonia is delivered from Incukalns UGS. Certain proportion of the natural gas resources is delivered back to Russia, the Pskov Region. Since 2006, the natural gas deliveries from the storage to Lithuania have also taken place, but Lithuania is not dependent on these supplies either in summer or in winter season, because it receives natural gas all year round via natural gas pipeline Minsk - Kaliningrad, and, since January 2015, from its floating liquefied natural gas import terminal in Klaipeda (hereafter - Klaipeda LNG terminal).

However, Incukalns UGS is one of the several approved large scale aquifer UGSs in Latvia, and currently the only one in operation. According to the technical studies done in 1970s, there are at least eleven more geological structures in the country suitable for the development of similar or lager natural gas storage facilities. The amount of natural gas for these storages varies from 2 till 17.5 BCM. [3]

In Latvia, like in some parts of Europe, Russia and the United States, there is a potential to develop large scale aquifer UGSs, as so called natural aquifers can be effectively converted to natural gas storage reservoirs. An aquifer is suitable for natural gas storage if the water bearing sedimentary rock formation is overlaid with an impermeable "cap". While the geology of aquifers is similar to depleted production fields, their use in natural gas storage requires more cushion gas (about $50 \%$ of all natural gas resources injected into the UGS) and more careful monitoring of withdrawal and injection performance.

Because of its unique geological prerequisites, Latvia has a potential for the development of the system of UGSs with the total volume of the natural gas up to $50 \mathrm{BCM}$. Estimates show that the above-mentioned eleven prospective UGSs could be developed in several parts of Latvia, with Zemgale and Kurzeme regions being the riches in appropriate geological formations. Seven out of eleven prospective UGS are located there. [4]

Among them, Dobele Structure (hereafter - the Structure) stands out as the only one that has been studied and where test drilling has been performed to confirm the estimated volume of the storage capacity, which is about $10 \mathrm{BCM}$. The Structure covering more than 46 square kilometers $(\mathrm{km} 2)$ is located mainly in the territory of Dobele District, the South Western part of Latvia. The central part of the Structure is located $12 \mathrm{~km}$ 
from Dobele and approximately $70 \mathrm{~km}$ from the capital of Latvia, Riga. [5]

\section{GENERAL INFORMATION ON THE STRUCTURE}

The Structure is located in the south-east part of Highland of Austrumkursa, in Lielauce hilly terrain; not far from the socalled contact area of Spārnene wavy low-land. Despite the large area of the object under discussion, it fits completely in one nature area - Lielauce hilly terrain. Today's relief varies from very weakly wavy and gently wavy to wavy or hilly (within the so-called Zebrus - İles ridge, in Sila and Krievu mountains).

The highest mark of today's relief (Silakalns) is $141 \mathrm{~m}$ above sea level (hereinafter - msl), but mainly the relief marks vary from $95-105 \mathrm{~m} \mathrm{msl}$ in the segmented areas and $85-90 \mathrm{~m} \mathrm{msl}$ in the low-land. Two lakes - Zebrus and Svētes - originate in the relief; they once might have been a single water body.

Wide, paludified lower areas are characteristic of the territory under discussion, they have originated when the united shallowest pre-lake part in east - west direction overgrew, as well as when the banks of Zebrus and Svētes lakes became paludified. In this manner, Zebrus, Elkus, and Lielais marshes have formed. [4]

Among other, the variety of nature conditions requires additional attention to environmental protection issues during geological research.

Surface of the mid-Cambrian reservoir in wells in the lifted part of the formation is exposed at a depth of 1050-1186 m. Its total thickness is $78-112 \mathrm{~m}$, its effective thickness according to carottage data is $52-89 \mathrm{~m}$, while operational one is $37-67 \mathrm{~m}$. Temperature of the mid-Cambrian reservoir is anomalously low, and in the lifted part of the structure it does not exceed $10.2^{\circ}-18.2^{\circ}$.

Aquifer related to the mid-Cambrian sandstones contains heavy mineralized pressure waters of chlorinated lime type with mineralization of $108-119 \mathrm{~g} / \mathrm{l}$. These waters belong to hydrogeologically closed zone of stagnation regime. Pressure of hydrostatic stratum is $106-147$ bar.

According to analytical research of the well core, sandstones porosity coefficient varies within the borders from $10 \%$ to $31.4 \%$. Respectively, the amount of remaining water varies in the reverse order from $8 \%$ to $65 \%$. [5]

\section{RESEARCH AND EXPLORATION}

Dobele high was discovered in the surface of crystalline bedrock in 1969 as a result of regional research using magnetotelluric profiling methods (MTP, Russian MTП), performed by geophysicians of the Latvian Geology Board. In 1970 the high was verified in the Paleozoic rocks by two profiles of the reflected wave method (RWM, Russian MOB). A year later the structure (high with a fault) was recommended for making oil test drills.

In 1971-1972 hydrogeological expedition of the Latvian Geology Board drilled two structural wells No. 91 and 92. The wells were made in the dome of the formation, behind the fault in the inclined block. The wells revealed bedrocks, but either oil or gas deposits were not discovered. Study of the well cores demonstrated that the Cambrian sandstone stratum has high collector properties.

In 1974, on the basis of the summarized material A. Freimanis and O. Semjonov offered to use the Structure as a potential object for the establishment of UGS in the Cambrian reservoir safely shielded by the sub-Ordovician clays. In 1983 the mentioned authors recommended to begin test drills to find out the opportunities for setting up the storage.

The company "Sojuzburgaz" conducted the research of the area in three stages - test drilling, preliminary research and detailed research. Works were performed from 1987 till 1990. [6]

Twenty wells were drilled here and all but two of them (14 and 18) exposed the Cambrian sediments. The results of the research conducted are summarized in several reports of "Sojuzburgaz". On the basis of these results, the source data for technological design of new gas storage facility were prepared.

Additionally, in 1991 the experts of Underground Storage Department of VNIIGAZ offered an option of technological indicators for Dobele UGS project with the amount of active gas of $3 \mathrm{BCM}$. According to the estimates, to make the storage suitable for accommodating so large amount of active gas, it would be necessary to drill 32 operational wells, equip a compression station with the capacity of $35.6 \mathrm{~kW}$ and inject 3 $\mathrm{BCM}$ of cushion gas.

Taking into consideration the Structure's favorable geological properties and location, 23 wells (including 12 operation wells; now 22 wells can be found on site) were drilled there. It was attested that the Structure can be used for the development of the underground gas storage facility with the total gas volume of about 10 BCM and active gas of 5 BCM. [6]

This information was re - affirmed by the study on the Latvian UGS potential carried out by the Baltic Energy Corporation, CMS Gas Transmission and Storage Company and Michigan University in 1997. [7]

As a result of drilling works, it was discovered that the Structure's structural high in the surface of the mid-Cambrian formation is a brahianticlinal fold orientated northeast with the size $16.5 \times 5 \mathrm{~km}$ and amplitude of up to $110 \mathrm{~m}$. Its northwestern flank, north-eastern and south-western periclines are flat, south-eastern flank is steep, it is of flexural type. Fault plane is a steep slope in north-western direction, where the fault has a step character with a few fault planes with the amplitude $18-28 \mathrm{~m}$. Its decrease behind borders of the high is possible.

However, the interest in prospective development of Dobele UGS declined in the late 1990s and early 2000s, while only in 2008 the explorative and administrative activities in this regard were reinitiated. They were initiated as a consequence of Informative Report prepared by the Ministry of Economics of the Republic of Latvia in February of 2006. The report itself was prepared by the group of experts from the Ministry of Economics, the Ministry of Environment and the Ministry of Foreign Affairs reviewing the priority underground gas storage structures, which, under favorable investment availability conditions, could have been developed as UGS in the future. The report identified Dobele structure as the first priority to investigate the possibilities for underground gas storage 
development. [11] The general interest project "Geological and Economic Research of Possible Establishment of Natural Gas Storage Reservoirs in Latvia, Dobele District" 2006-G 130/06TREN/06/TEN-E-S07.68968 (funded by the European Commission (hereafter - EC)) was launched and the area of the Structure covering a section of $99.2 \mathrm{~km} 2$ had been outlined. Its boundaries have been determined by the Cabinet of Ministers Regulations No. 524 "Regulations on the Use of the Section of Subsoil of National Significance the "Dobele Structure"" of July 7, 2008 (hereinafter - the Regulations). [2]

\section{INSPECTION OF THE WELLS}

Pursuant to agreement No. 826 of 7 December 2009, geophysical research was performed in the wells of the section of the Structure indicated by the Regulations in order to determine their technical condition and possibilities of further use.

During the inventory, technical specialists tried to locate all 23 wells that had been historically drilled in the Structure, however, the research showed that only 22 out of original 23 wells exist in the Structure. The efforts to locate well No 15 turned out to be unsuccessful. Immediate inspection of the located wells showed that two of them are closed-up, filled with cement, according to the requirements stated for the closing-up of the deep wells.

A complex of geophysical research comprised gamma carottage, defectoscopy of magnetic impulses, acoustic cementometrics, high sensitivity termometrics, acoustic defectoscopy of waves and additional methods - magnetic location and barometrics of shellpipe caps. [4]

The results of the well inspection showed that technical condition of three wells (5, 7 and 12) is satisfactory, and they, after cleaning the well base, pressing and equipping with respective over ground and underground facilities can be used as either operational or observation wells. Considering medium cementation quality of shell pipes, after launching gas injection control firmly inter colon pressure.

Another three out of twenty two wells $(8,11$ and 16) were reported to be in adequate technical condition, but, taking into account their location behind tectonic fault in the inclined block of the formation, it was recommended to use them as observation, not operational wells.

Therefore, during geophysical research of the Structure, technical condition of 6 out of 20 wells revealing the Cambrian sediments was assessed. 3 of the assessed wells are located in the inclined block of the formation and therefore cannot pose gas leak threat.

The working group of scientists also drew main conclusions and made recommendations for further activities that should be carried out in evaluation of the Structure's wells.

It has been indicated that well 17 is located far from planned main pumping test area $(14,18)$, relatively working and potentially working wells 7 and 12 are located nearby, so purging of well 17 could not be economically feasible. Well 1 is close to the planned main pumping test area and might be used as observation well for water level monitoring. The necessity for well gauging has been discovered in 6 wells $(2,3$,
$4,5,6,9, \mathrm{~W})$ located outside the planned area of seismic survey, therefore they cannot be used as base points in the interpretation of seismic data and there is no need for geophysical logging in these wells. These wells, except 5, were not needed for the hydrodynamic investigations, too. Well 3 was said to be the most suitable for the discharge of the pumped water, as it is located far away from the pumping test area and the water level in the well is deep. Therefore, well gauging would be recommended in those wells in order to specify well depth and screen interval condition.

Detailed geological cross section is available in the State Geological Fund for wells 1-5, therefore, there is no geological need for well logging. But wells 1 and 5 might be used as observation wells for the pumping test, thus well gauging is recommended.

It has also been stressed by the experts that there are 15 more wells left in the Structure that are potentially suitable for further operation and therefore require in depth technical assessment and investigations.

As it was mentioned before, 2 wells (91 and 92) were closed up long time ago, and there is no need to disturb them from now on, but 8 wells $(2,4,6,9,10,15,17, \mathrm{E})$ due to different obstacles like being filled up, littered, impossible to be located, or being unnecessary cannot be used at all. Well gauging was recommended in 15 wells $-1,3,5,7,8,11,12,13,14,14 / 1$, $14 / 2,16,18,18 / 1$ and W. Short-term pumping-injection tests should be performed in those wells, too, in order to determine screen quality, except wells 12, 18 and 18-1, where it has already been done;

The list of wells for geophysical logging should be defined after obtaining the well gauging and short-term pumpinginjection test results. [4]

\section{ENVIRONMENTAL PROTECTION}

Although physical influence of geological research works (noise, vibrations of various frequency range) on the environment has not been sufficiently studied, it can be stated with a high degree of certainty that the direct influence of the methods to be used on the environment can become apparent not further than in $10-20 \mathrm{~m}$ distance from the particular research point (well).

The impacts on the environment connected with the geological research will be mainly short-term, that is, they will become apparent during the works and will cease when their performance is finished. Taking into account the abovementioned, as well as the fact that the greatest amount of works necessary for research of the Structure's reservoir was performed long ago (more precisely - the establishment of the wells), the influence of the activities under discussion on the environment is not assessed to be significant.

The abovementioned does not mean, however, that the issues connected with environmental protection are or can be ignored during the geological research. The Geological Research Program does not provide any information on the possible impact of research works on the environment and possible mitigation measures concerning the hazard to the environment. The use of heavy equipment, which is inevitable in absolutely 
all planned research works - both in seismic and hydrodynamic works, as well as additional research or carottage works of the wells, might cause the main problems during the research under discussion.

Below, the restrictions that are to be taken into consideration when performing geological research works in the territory of the planned gas storage reservoirs are reviewed.

Taking into consideration Clause 12 of the Cabinet of Ministers Regulations No. 524, the executer of seismic and/or other kind of research works envisaged in a land plot will have to conclude a separate agreement with each of the owners of the land plot. In case the owner or lawful possessor of the land concludes such an agreement, he will have no rights to limit or hinder the research in any other way. In compliance with the abovementioned Cabinet of Ministers Regulations (Clause 13), the works are to be performed in the period when cropland is not employed with agricultural crop, namely from late autumn until early spring (approximately from November until midMarch). If the agricultural land is used for sowing of winter crops, seismic research works can be performed only when the cropland in completely frozen or in case of deep snow. [11]

In case the owner of the land refuses to conclude an agreement on research, neither seismic, nor other works in particular land plot can be performed. Thus, this is the first and the most significant limiting factor.

The second limiting factor is connected with the fact that part of the research territory is situated in the territory of the nature reserve "Lake of Zebrus and Lake of Svētes". In compliance with the Cabinet of Ministers Regulations No. 390 "Regulations on Individual Protection and Use of Nature Reserve "Lake of Zebrus and Lake of Svētes"' as of May 16, 2006, it is not allowed to drive off the roads and move by mechanic vehicles on forest or agricultural lands if it is not connected with the management or supervision of these territories (Clause 13.5). This has been already taken into consideration in the Geological Research Program, excluding this area from the research territory, moreover, the marsh areas in the south and south-east from Zebrus Lake (Zebrus, Elkus and Lielais) are not accessible for the heavy equipment.

Accessibility is the third limiting factor. Usually heavy motor vehicles involved in performance of seismic works cannot pass through marshes and dense forest areas. This factor, however, cannot be considered completely limiting, because usually drilling of small wells can be organized in such territories, and explosions in the wells or pneumatic vibration sources immersable in the wells can be used as elastic vibration sources. However, it should be observed that use of explosive materials leads to a range of other limitations.

Damage of technical character in the upper part of the covering tubes of the wells should be considered as another limiting factor, because within 18-20 years since the establishment of the wells at least some of them might not be usable.

If the requirements of the Regulations are interpreted literally: When performing research of the section, it is prohibited for the license recipient to drain the withdrawn groundwater on the surface and groundwater horizons (Clause
10), hydrodynamic research would not be possible. In the Geological Research Program, the following interpretation of this clause has been proposed: the withdrawn underground water can be drained back into the same horizon from which it was withdrawn. As a matter of fact, considering such draining back, the aim of the abovementioned regulatory enactment is not violated unless the underground water is polluted during the circulation cycle. There is no other option how to perform the planned research, because the literal interpretation of the abovementioned clause would make the research completely meaningless, and thus would have a negative impact on the object for the needs of which the Regulations have actually been adopted.[3]

All other practical limitations have already been considered in the Geological Research Program in complete compliance with the feasibility, admissibility and assessment of the limiting factors, as well as the recommendations from the environmental point of view of the general interest project "Geological and Economic Research of Possible Establishment of Natural Gas Storage Reservoirs in Latvia, Dobele District" 2006 - G 130/06TREN/06/TEN-E-S07.68968 - geological research in compliance with part 2, project work task, as elaborated in 2008 by "Eiroprojekts" Ltd, funded by European Community Commission.

\section{CONCLUSIONS}

Possible development of Dobele UGS facility could be based only on further evaluation of the project's technical and economic feasibility. The area of the structure is larger than the area covered by the seismic survey in the late 2000s.

Thus, to some extent, the dimensions of the structure are not completely clear. Additional seismic survey can provide the data on the geological conditions, which quite likely may increase the currently calculated capacity of the storage.

Technical outlines or precise plans of Dobele UGS's integration into the Latvian natural gas infrastructure should be developed with regard to significant changes, if any, of the existing high pressure natural gas grid.

Further studies are required in order to define the expected functions of Dobele UGS as the element of transnational natural gas supply security guaranty with and without the foreseen additional commercial use of this facility.

\section{REFERENCES}

[1] The law "On the Subsoil" ("Par zemes dzīlēm"): http://likumi.lv/doc.php?id=40249

[2] Cabinet Regulation No. 524 Regulations for Use of the Section of Subsoil of National Significance the "Dobele Structure" http://www.vvc.gov.lv/advantagecms/LV/meklet/meklet_dokumentus.ht $\mathrm{ml}$;jsessionid=ED4A542B9398F3053E9E95EDB4CEE915?query=natio nal+security\&searchPage $=62 \&$ resultsPerPage $=10$

[3] Ministru kabineta noteikumi Nr.390 Dabas lieguma "Zebrus un Svētes ezers" individuālie aizsardzības un izmantošanas noteikumi, http://likumi.lv/doc.php?id=135252

[4] Valsts nozīmes zemes dz̄ị nogabala „Dobeles struktūra” ǵeoloǵiskās izpētes rezultāti (2010), Gala ziṇojums, Vol. 1, 1-138

[5] I. Niedrite, A. Davis, N. Zeltins (2014) Evaluation of the Level of Security of Gas Supply on the Example of Latvia // WEC 10 $0^{\text {th }}$ International Energy Conference: Efficiency in Resources Management, Excellency in Energy Industry, Niroo Research Institute of Iran (NRI), August 26-27, 2014, 
Tehran-Iran, Abstracts of English and Farsi Papers: 235 p. http://irannec.com/English/default.aspx $7 \mathrm{pp}$

[6] K. Mikelsons, A. Davis, V. Zebergs, N. Zeltins "Latvian Underground Gas Storage Facilities for the Development of a Safe Gas and Power Supply System of North European Gas"/IRAEE International Conference on "Energy \& Security in the Changing World" (2004), Teheran, Iran, CD $-10 \mathrm{pp}$.

[7] A. Davis, A. Jesinska, A. Kreslins, V. Zebergs, Zeltins N. “ Increasing Role of Underground Gas Storages For Reliable Supply of Gas to Latvia, Lithuania, Estonia, Finland and NW Russia and Prospects of Development of Incukalns Underground Gas Storage" // 23rd World Gas Conference, Amsterdam (2006), CD - 13 pp.

[8] L. Jansons, N. Zeltiņš, A. Dāvis, J. Savickis (2014) The Latvian UGS Potential for Improvement of the EU's Security of the Natural Gas Supply: a Midterm Perspective // WEC $10^{\text {th }}$ International Energy Conference: Efficiency in Resources Management, Excellency in Energy Industry, Niroo Research Institute of Iran (NRI), August 26-27, 2014, Tehran-Iran, Abstracts of English and Farsi Papers: $221 p$. http://irannec.com/English/default.aspx $12 \mathrm{pp}$.

[9] J. Ekmanis, V. Zebergs, N. Zeltins, A. Davis, "Risk-reducing Problems of the Latvian Gas Supply// Int. J. Global Energy Issues, 34, Nos. 1/2/3/4, (2010) Inderscience Enterprises Ltd., London: 78-90

[10] I. Niedrite A. Kreslins, A. Davis, N. Zeltins "Security of Gas Supply Risk Assessment Alternatives" // Proceedings of 22th World Energy Congress, Daegu, Korea 17 October (2013) Nr 820 - 14 pp.

[11] Informatīvais ziņojums "Par iespējām sekmēt zemes dzīḷu derīgo īpašību izmantošanu valsts ekonomiskā potenciāla paaugstināšanai”: tap.mk.gov.lv/doc/2005/EMZino_260606.doc 